\title{
Lincoln Park Shoreline Erosion Control Project: Monitoring for Surface Substrate, Infaunal Bivalves and Eelgrass, 1993
}

L. D. Antrim

R. M. Thom

W. W. Gardiner

September 1993

Prepared for the U.S. Army Corps of Engineers Seattle District under a Related Services Agreement with the U.S. Department of Energy under Contract DE-AC06-76RLO 1830

Pacific Northwest Laboratory Operated for the U.S. Department of Energy by Battelle Memorial Institute 
PNL -8822

UC -000

LINCOLN PARK SHORELINE EROSION CONTROL

PROJECT: MONITORING FOR SURFACE SUBSTRATE, INFAUNAL BIVALVES AND EELGRASS, 1993

L. D. Antrim

R. M. Thom

W. W, Gardiner

Battelle/Marine Sciences Laboratory

Sequim, Washington

September 1993

Prepared for

the U.S. Army Corps of Engineers - Seattle District under a Related Services Agreement

with the U.S. Department of Energy

Contract DE-AC06-76RLO 1830

Pacific Northwest Laboratory

Richland, Washington 99352

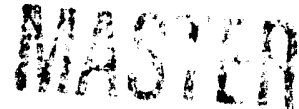




\section{SUMMARY}

In 1988, the U.S. Army Corps of Engineers and the City of Seattle placed fill material on the upper beach at Lincoln Park, in West Seattle, Washington. The fill served to mitigate shoreline erosion that had caused undercutting and collapse of the seawall in several places. A series of pre- and postconstruction studios have been conducted to assess the impacts to marine biota of fill placement and subsequent movement of surface substrates.

This study was designed to monitor infaunal bivalves and eelgrass from intertidal areas in and adjacent to the area of original fill placement. Findings from this survey were compared to previous survey results to determine 1) if recruitment of infaunal bivalves to the fill area has occurred, 2) if infaunal bivalve densities outside the fill area are stable, and 3) if eelgrass distribution and abundance have remained stable along the adjacent shoreline. To maximize comparability of findings from this survey with previous studies, sampling techniques, transects, and tidal elevations were consistent with previous studies at this site.

While much of the seawall at Lincoln Park remains protected by fill material placed in 1985, a migration of cobble has occurred on lower beach elevations and on the beach south of the park boundary. The clam populations at Lincoln Park appear to be stable. Three measures of infaunal bivalve community (density, size, and species distribution) indicate that the current populations at Lincoln Park are very similar to pre-fill conditions in 1985.

The size and shape of eelgrass (Zostera marina) patches have been variable between different studies. Nevertheless, eelgrass has remained established in most areas where it was been found before fill material was placed on the upper beach. In addition, new patches of eelgrass were located in 1993 that had not been identified in earlier studies. Eelgrass was transplanted from larger patches to an area with suitable substrate where eelgrass beds were documented in previous surveys. 


\section{ACKNOWLEDGMENTS}

We appreciate the competent and generous field support from Sara Hinds. Laura Gully is owed thanks for her help with report preparation. Heathe Robinson and Maria Pehling were capable assistants for the eelgrass transplanting. Ray Bienert provided an excellent peer review. Funding for this project was provided by the U.S. Army Corps of Engineers, Seattle District. We have appreciated working with Steve Martin, at the Seattle District, who fostered a professional and comfortable working relationship. 


\section{CONTENTS}

SUMMARY ..............................

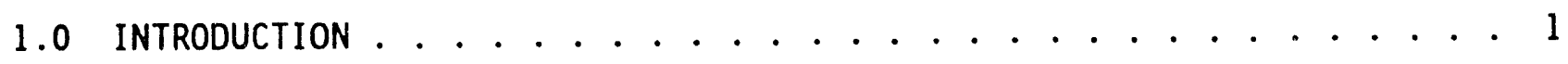

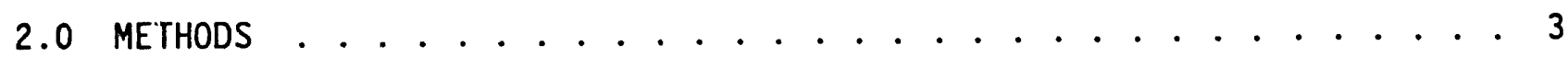

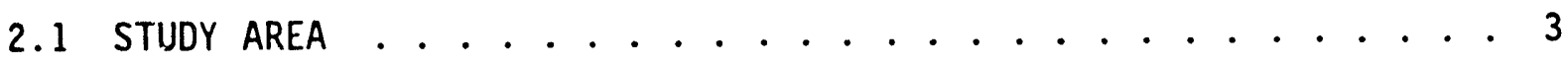

2.2 FIELD SAMFiING . . . . . . . . . . . 5

2.2.1 Substrata and Bivalves............. . 5

2.2 .2 Eelgrass ............... . . . 5

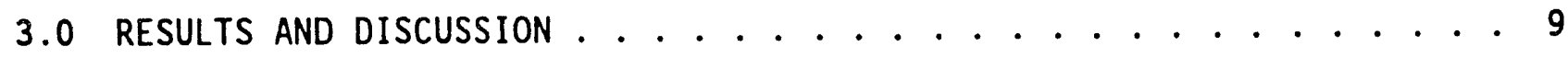

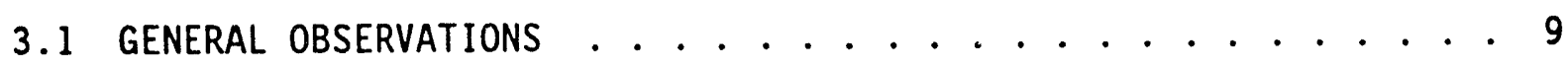

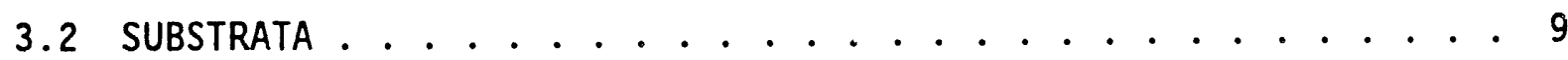

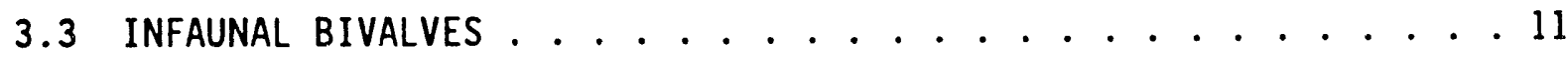

3.3.1 Density .................. . . 11

3.3.2 Bivalve Biomass and Valve Length......... 14

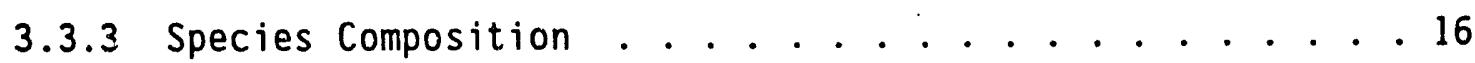

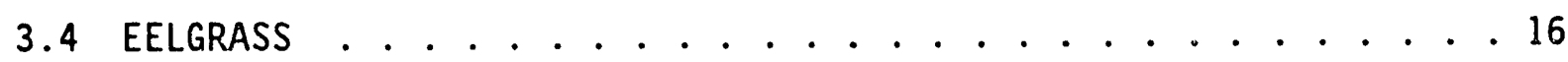

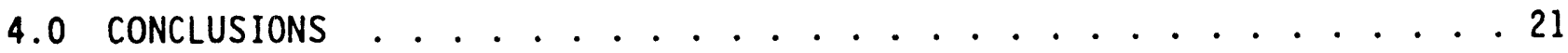

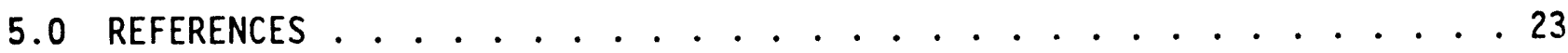

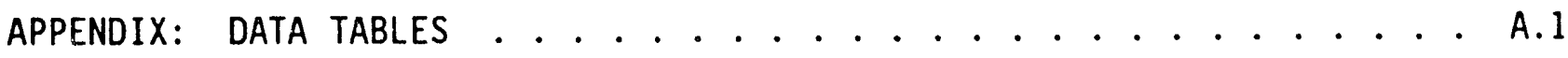




\section{FIGURES}

2.1 Transect Locations at Lincoln Park . . . . . . . . . . . . . . . . 4

3.1 Location of Eelgrass Patches Found in 1993 and Approximate Toe of Fill in 1990 and 1993 ................. 12

\section{$\underline{\text { TABLES }}$}

3.1 Summary Statistics for Substrata and Infaunal Bivalves at Lincoln Park: 1985-1993 .................. 10

3.2 Mean and Standard Deviation for Infaunal Bivalve Density and Biomass from Fill Area and Reference Area Stations

at Lincoln Park: 1985-1993 .................. 10

3.3 mean and Standard Deviation for Value Length of Three Dominant Infaunal Bivalve Species at Lincoln Park: 1985-1993 . . . . . . . . 15

3.4 Eelgrass Monitoring Data and Observations, May 1993 . . . . . . . . 18 


\subsection{INTRODUCIION}

In the fall of 1988, the U.S. Army Corps of Engineers - Seattle District, and the City of Seattle completed a project to rehabilitate the seawall and beach at Lincoln Park, in West Seattle, Washington. The project was designed to mitigate shoreline erosion that had caused undercutting and collapse of the seawall in several places. One aspect of the rehabilitation effort was placement of $\mathrm{fill}$ on intertidal areas between $+8 \mathrm{ft}(2.4 \mathrm{~m})$ and $+4 \mathrm{ft}(1.2 \mathrm{~m})$ mean low low water (MLLW). Fill material was selected to duplicate substrate that would naturally be found at the site.

A series of pre- and post-construction studies have been conducted to assess the impacts to marine biota of fill placement and subsequent movement of surface substrates. In 1985, Thom and Hampel (1985) completed a pre-baseline study of benthic biota that focused on macroalgae and infaunal bivalves occupying intertidal areas in and adjacent to the area of fill placement. The dominant bivalves identified were Protothacea staminea (1ittleneck clams), Saxidomas giganteus (butter clam), and Macoma sp. Additional baseline studies focused on benthic fish prey resources (Hiss et al. 1988) and eelgrass, Zostera marina L. (Thom 1988).

Post-construction studies of substrata, benthic infauna, and macroalgae were completed in 1989 (Thom and Hallum 1989) and 1990 (Thom and Hamilton 1991). These studies documented slumping of finer-grained materials from the area of fill placement to lower elevations on the beach. Higher elevations in the fill area had not been colonized by infaunal bivalves in 1990. This finding, however, was not surprising. Higher intertidal elevations typically do not support abundant populations of infaunal bivalves. Mnreover, the duration after fill placement may not have been sufficient to allow for establishment of bivalve populations.

The purpose of this study was to monitor infaunal bivalves and eelgrass from intertidal areas in and adjacent to the area of original fill placement. Findings from this survey in 1993 are compared to previous survey results to determine 1 ) if recruitment of infaunal bivalves to the fill area has occurred, 2) if infaunal bivalve densities outside the fill area are stable, and 3 ) if eelgrass distribution and abundaince have remained stable along the 
adjacent shoreline. To maximize comparability of findings from this survey with previous studies, sampling techniques, transects, and tidal elevations were consistent with previous studies at this site.

In addition to the introduction, this report contains a description of the study area and field sampling methods in Section 2.0 (Methods); a review of observations related to substrate, infaunal bivalves, and eelgrass in Section 3.0 (Results and Discussion); a summary of findings in Section 4.0 (Conclusions); a list of cited publications in Section 5.0 (References); and a complete tabulation of data in an attached appendix. 


\subsection{METHODS}

\subsection{STUDY AREA}

Sampling for infaunal bivalves (clams) and surface substrata occurred at 11 transects established by Thom and Hampel (1985) (Figure 2.1). These same transects have been used in pre- and post-construction infaunal bivalve studies conducted at Lincoln Park (Thom and Hampel 1985; Thom and Hamilton 1991). Transects 2 through 9 were within the area of original fill placement. These transects were originally established using one randomly selected point on the seawall from which additional transects were defined at $100-\mathrm{m}$ intervals. Two reference-area transects, Transects 1 and 10, were located to the north and south, respectively, of the fill area. Details of transect selection and location are provided in Thom and Hampel (1985). The fill area, or area of original fill placement, is defined by sampling stations at $+4 \mathrm{ft}$ and $+6 \mathrm{ft}(1.8 \mathrm{~m})$ MLLW elevation [and $+8 \mathrm{ft}$ in 1985 and 1990] at Transects 2 through 9. The reference area includes tidal elevations below the fill area $[+2 \mathrm{ft}(0.6 \mathrm{~m}), 0 \mathrm{ft}(0 \mathrm{~m})$, and $-2 \mathrm{ft} M L L W]$ at Transects 2 through 9 and all sampling stations at reference transects (Transects 1 and 10).

In 1993, transect heads were measured at $100-\mathrm{m}$ intervals and marked along the seawa11, starting with Transect 9. Sampling stations along each transect were located at $2-\mathrm{ft}(0.6-\mathrm{m})$ intervals from $+6 \mathrm{ft}$ to $0 \mathrm{ft}$ MLLW according to magnetic angles and distances used in 1990 (Thom and Hamilton 1991). Three additional sampling stations were located at $+4 \mathrm{ft}$ MLLW midway between Transects 5 and 6,6 and 7 , and 8 and 9 . These stations were added to supplement sampling at the lower elevation limit of the fill area, where bivalve recruitment would be most likely. Sampling at the $+8-\mathrm{ft}$ MLLW elevation was eliminated in 1993 because this elevation was hiyher in the intertidal zone than infaunal bivalves are normally found. No clams have been found at this elevation in previous studies at the study site. In 1993, the tidal elevation at $0-\mathrm{ft}$ MLLW stations was verified with reference to the predicted tidal height from U.S. government tide table information for Seattle. 


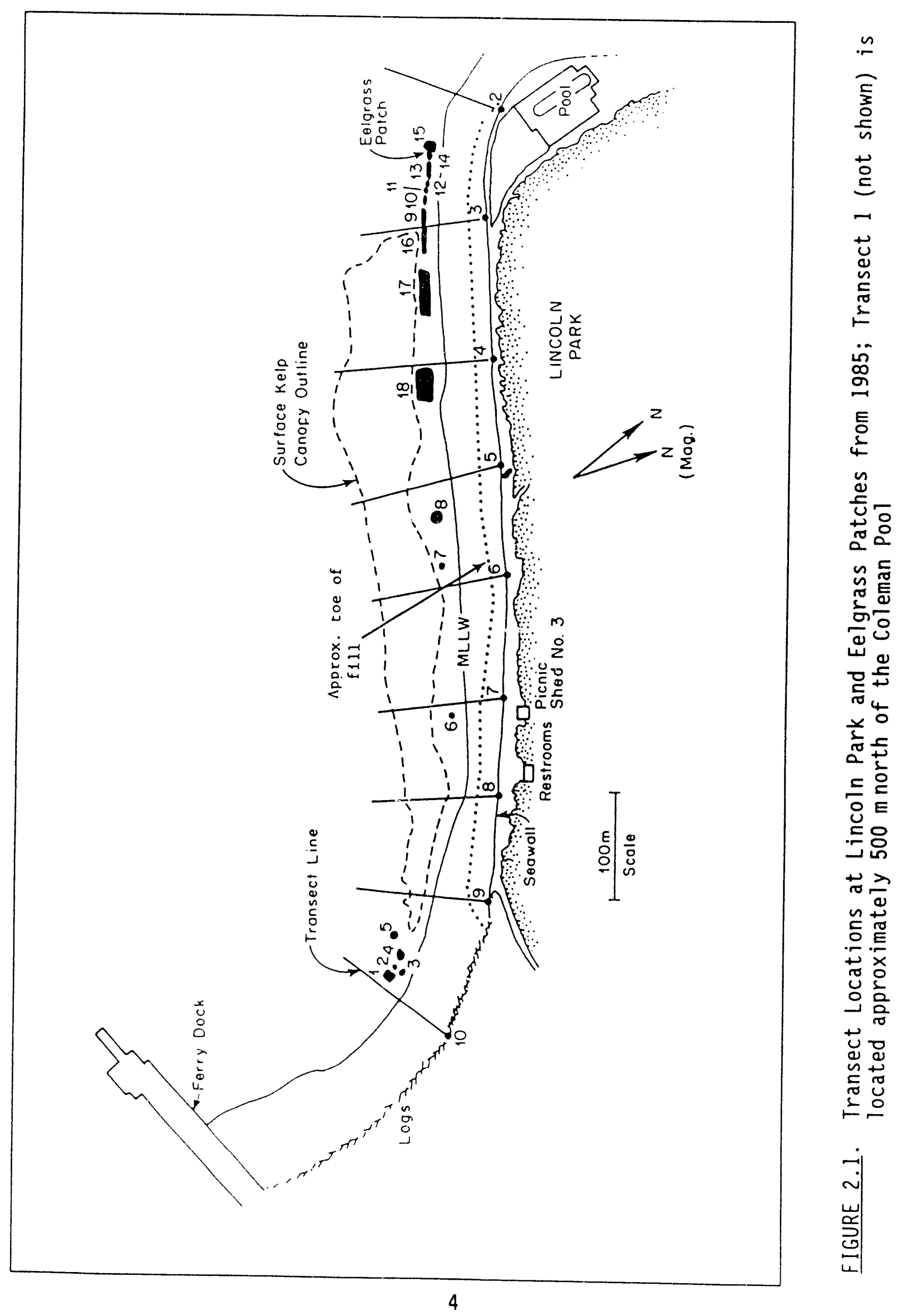




\subsection{FIELD SAMPLING}

\subsubsection{Substrata and Bivalves}

Field sampling for substrata and bivalves was conducted March 10 through 12, 1993. At each sampling station, a clear plastic $0.1-m^{2}$ quadrat with 50 randomly selected points was used to determine substrate cover. Substrate type under each point was characterized as cobble (5- to $15-\mathrm{cm}$ diameter), gravel (0.2- to $5-\mathrm{cm}$ diameter), or sand $(<0.2-\mathrm{cm}$ diameter). A methodical survey of beach topography was not completed for this study. Because sampling occurred in early spring, macroalgal cover was not well established, and it was not characterized for this study.

Infaunal bivalves were sampled at the saze stations monitored for substrata. At each sampling station, bivalves were collected from a $25-\mathrm{cm} X$ $25-\mathrm{cm}$ area $\left(0.06-\mathrm{m}^{2}\right)$ excavated to a depth of $\geq 30 \mathrm{~cm}$. Bivalves were retained on a $1.3-\mathrm{cm}$ screen and placed in bags for transport to iite laboratory. Sediments passing through the screen were examined for the presence of small bivalves $(<1.3 \mathrm{~cm})$.

In the laboratory, bivalves were identified by species, and the valve length was measured using calipers. The dry weight of soft tissues was determined after tissues had been separated from the shells and dried at $60^{\circ} \mathrm{C}$ for $24 \mathrm{~h}$.

\subsubsection{Eelgrass}

Monitoring of eelgrass (Zostera marina) was conducted on May 6, 1993. An initial attempt on April 8 was hindered by onshore winds and breaking waves, which limited access and visibility at low intertidal and subtidal areas. The monitoring approach for eelgrass was designed 1) to replicate sampling techniques used for previous studies, 2) to locate and monitor previously identified eelgrass patches, 3) to survey for eelgrass patches established since 1990 monitoring, and 4) to survey the study area for suitable eelgrass substrate. Since 1985, eelgrass monitoring at Lincoln Park has used 0-ft MLLW stations identified in 1985 at each transect (Transects 2 - 10) as the baseline for location of eelgrass patches. In 1993, these stations were marked with flagged stakes. Patches of eelgrass were located and surveyed for the following characteristics: patch shape, size (length, width, or 
diameter), tidal elevation, shoot density, general substrate characteristics, and location relative to the nearest flagged stake. Shoot density was estimated from a $0.1-\mathrm{m}^{2}$ quadrat randomly tossed in the patch one or more times. Water depth and highly turbid water during field sampling prevented shoot density measurements in some eelgrass patches. Tidal elevation was estimated from the $0-\mathrm{ft}$ MLLW stations.

Transplanting of eelgrass plants was completed on July 19, 1093, during an extremely low tide. Earlier transplanting efforts in the spring were hampered by several factors. Healthy beds of eelgrass are a limited resource in the area. At Lincoln Park beach, the only apparent source of eelgrass shoots for transplanting is near Transect 10 (patches 1-5). Removal of shoots from other areas at Lincoln Park is likely to have a negative impact on the eelgrass patches, which are relatively small, sparse, or limited to a narrow band on the beach. In addition, suitable substrate for eelgrass survival is limited along the lower intertidal and shallow subtidal beach adjacent to the fill area. During field sampling in the spring, breaking waves prevented access tc subtidal beach elevations with suitable eelgrass habitat (e.g., soft substrate).

In May and July 1993, the beach was surveyed for sites suitable for eelgrass transplanting and enhancement. Beach elevations below $0 \mathrm{ft}$ MLLW were examined for areas of soft substrate (i.e., sand and mud) that were free from significant vegetative colonization. Most of this elevation at Lincoln Park between the south boundary and the Coleman Pool is dominated by cobble and boulders or algae cover. A large area between Transects 5 ana 6 was selected for two reasons: 1) a large expanse of clean sand covered the bottom at $-2 \mathrm{ft}$ MLLW and deeper, and 2) eelgrass had been established in this area in previous years (patch 8 from Thom 1988, Thom and Hallum 1989).

Eelgrass stock for transplanting was dug from large, shallow subtidal patches near Transect 10, just north of the Fauntleroy ferry terminal. Mats of rhizomes were separated into pieces without excessive fractionation of the rhizomes. Shoots with living tlades were grouped into bundles of $5(n=30)$ or $10(n=25)$ and bound with paper and wire twist-ties. The majority of the eelgrass blades were approximately 0.3 to $0.6 \mathrm{~m}$ long. Eelgrass was kept moist during transport to the site selected for enhancement. At the enhancement 
site, eelgrass bundles were transplanted to their original depth in the sediment and spaced 0.4 to $0.6 \mathrm{~m}$ apart. Rhizomes were covered with sediment, and a hooked wire anchor ( $\geq 2.4 \mathrm{~cm}$ long) was pressed into the sediment to hold each bundle in place. Transplants were distributed into two rectangular patches centered at $20.8 \mathrm{~m}$ and $27.8 \mathrm{~m}$ from Transect 5, $0 \mathrm{ft}$ MLLW (1985 data). The transplants were placed between $-3 \mathrm{ft}(0.9 \mathrm{~m})$ and $0 \mathrm{ft}\{\mathrm{lLLW}$. The patch located $20.8 \mathrm{~m}$ from Transect 5, $0 \mathrm{ft} M L L W$, had a small number of plants near $+2 \mathrm{ft} \mathrm{MLLW.}$ 


\subsection{RESULTS AND DISCUSSION}

\subsection{GENERAL OBSERVATIONS}

Fill material or beach substrate was generally 0.3 to $0.6 \mathrm{~m}$ below the top of the seawall. Over most of the fill area, a band of logs formed a relatively level shelf approximately $2 \mathrm{~m}$ wide and provided some protection for the upper beach near the seawal1. A limited band of vegetation (e.g., dune grass and wild flowers) has established itself near the seawall on portions of the upper beach. Below the band of logs, the beach sloped more steeply toward the water. Although the bulk of the fill material appeared to have remained in the area of original placement, migration of the fill material was evident, as discussed below. Evidence of extensive disturbance from recreational clam digging was noted during field work in July 1993, particularly near Transects 4 and 5.

\subsection{SUBSTRATA}

Results of substrata characterization are combined with bivalve sampling data and summarized in Tables 3.1 and 3.2. Data from 1993 are presented with results from previous studies to allow for comparisons of pre-construction conditions (1985) and post-construction conditions (1990 and 1993). An increase in cobble on the beach surface at some locations indicated a migration of fill material outside the area of original placement. To analyze for these trends, substrate characterizations from 1993 were compared to data collected approximately one half year after placement of fill (Thom and Hamilton 1991). The values for substrate percent cover in 1990 may be misleading because the values for the four substrate types do not sum to $100 \%$. This is because other parameters (e.g., algal and barnacle civer) were included in the estimation of cover. For statistical analyses, 1990 substrate cover values were adjusted to total $100 \%$ for the four suhstrate types to accommodate this difference in the data.

A migration of cobble has occurred onto the beach south of the park boundary, toward Transect 10 . This observation was supported by a property owner who stated that the beach surface in the area south of the park had been predominantly sand. Data from 1990 indicate that surface substrate along 


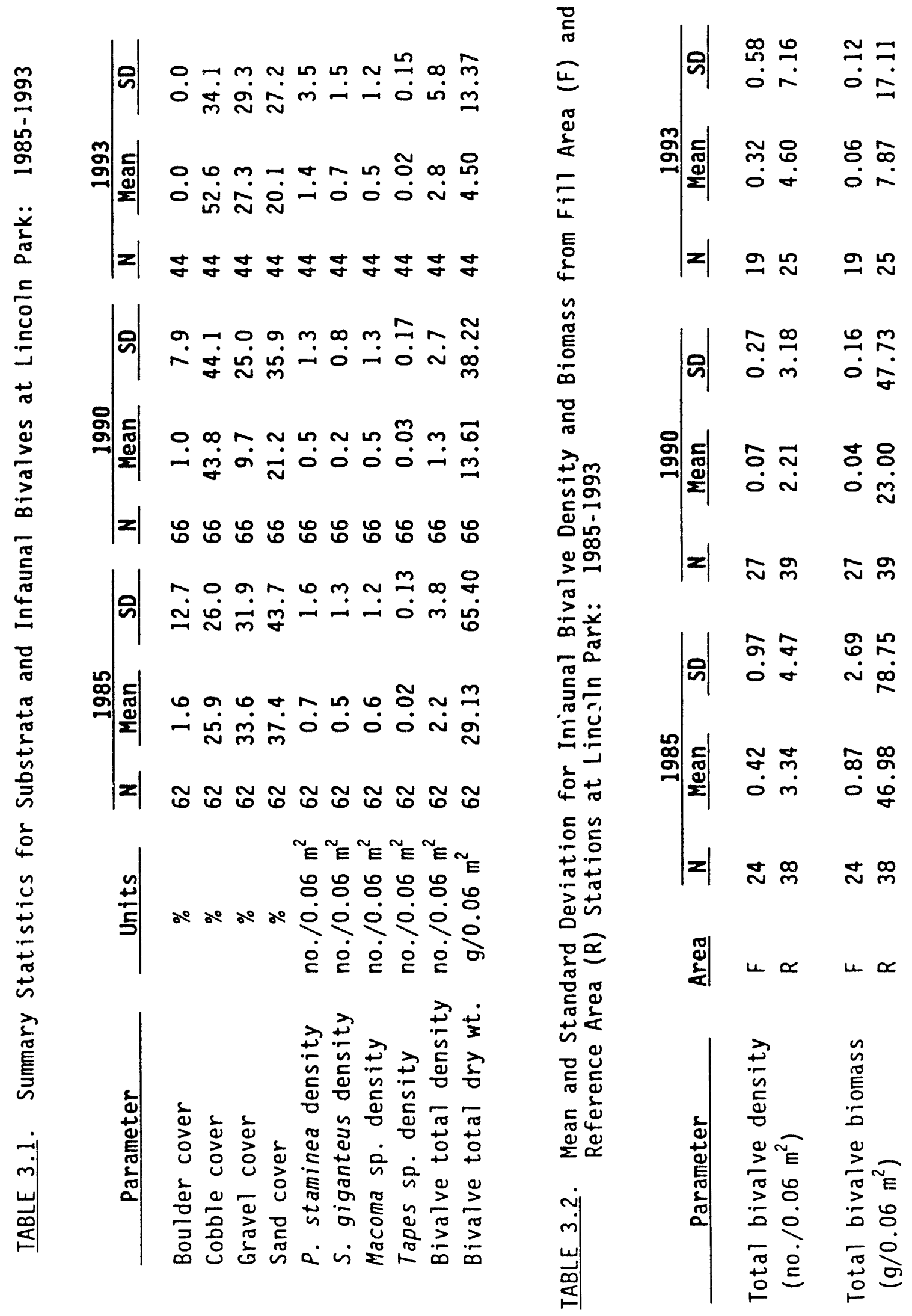


Transect 10 was dominated by gravei on the upper beach ( $\geq+2-\mathrm{ft}$ elevation) and sand or mud on the lower beach. In the spring of 1993, cobble formed the dominant substrate between $+2 \mathrm{ft}$ and $+6 \mathrm{ft} M L L W$ in a band that was continuous with Transect 9, the southern limit of initial fill placement. Comparison of 1990 and 1993 data indicates a significant increase in surface cobble deposits at Transect 10 between 1990 and 1993 ( $t$-test, $p<0.05$ ).

Over the entire study area there appears to have been a redistribution of cobble to beach elevations below the fill area. Although the mean percent cover by cobble decreased at $+4-\mathrm{ft}$ elevation: and increased at $+2-\mathrm{ft}$ elevations between 1990 and 1993, these differences were not statistically significant. Analysis of percent cover with cobble and gravel combined provides the same results. Figure 3.1 shows the study area with the location of the toe of fill in 1990 and 1993, as indicated by a substrata dominated by unvegetated cobble. It appears that fill material has migrated down the beach to lower elevations since 1990.

Accretion of sediments has occurred at Williams Point near the Coleman Pool (Transect 2). Sampling stations on Transect 2 from 1990 (based on distance from the seawal1) were approximately $2 \mathrm{ft}$ MLLW higher in 1993 than in 1990. As a result, sampling stations on Transect 2 were adjusted in 1993 to corrsspond to the appropriate tidal elevation. It is uncertain, however, if the source of these accreting sediments is fill material or other materials. In 1993, gravel and sand dominated stations at Transect 2, yet in 1990 cobble formed the dominant substrate.

\subsection{INFAUNAL BIVALVES}

\subsubsection{Density}

The density of infaunal bivalves in the fill area was sparse in 1993 (mean density $=0.32 \mathrm{clams} / 0.06 \mathrm{~m}^{2}$; Table 3.2). In 1993, a total of $6 \mathrm{clams}$ were found at 5 of the 19 sampling stations within the fill area. The majority (83\%) of the clams found in the fill area were littleneck clams, $P$. staminea. The only other species found in the fill area in 1993 was the butter clam, S. giganteus $(17 \%)$. No small bivalves $(<1.3 \mathrm{~cm})$ were noted in fill-area sediments that passed through the screen. 


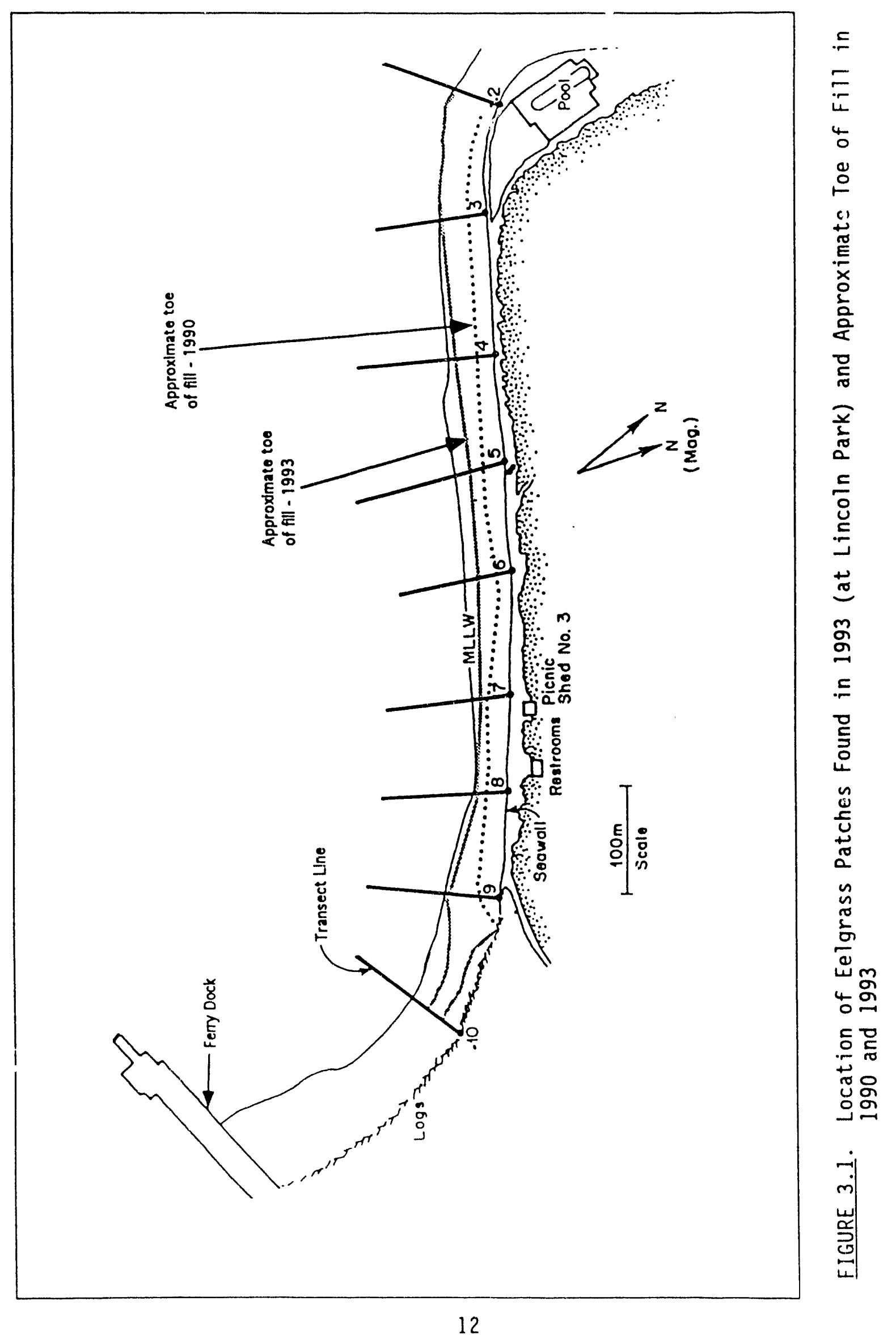


Previous surveys of infaunal bivalves also found clams at relatively few sampling stations and at low densities (Table 3.2). The pre-construction survey in 1985 (Thom and Hampel 1985) had 5 of 24 fill-area stations with bivalves. The first post-construction survey (Thom and Hamilton 1991) had 2 of 27 fill-area stations with bivalves. The upper limit of clam distribution has been $+6-\mathrm{ft}$ MLLW, where clams were found in 1985 (Transect 5) and 1993 (Transect 9). P. staminea has consistently been the dominant bivalve species in the fill area.

The high percentage of sampling stations with no clams present limits statistical tests for trends or between-year comparisons in bivalve density. For example, the mean of $0.07 \mathrm{clams} / 0.06 \mathrm{~m}^{2}$ in 1990 was based on clams in only $7 \%$ of the sampling stations from the fill area. When this occurs, data are better examined using tests of association (i.e., $\mathrm{R} \times \mathrm{C}$ contingency tables; Snedecor and Cochran 1980) rather than conventional comparison tests (e.g., $t$-test or analysis of variance).

No significant association was found between infaunal bivalve density in the fill area and survey year $(p-0.1)$. This means ihore has been no detectable change in infaunal bivalve density in any of the three years of study. Mean infaunal bivalve density in the fill area has been consistently low, ranging from 0.07 to $0.42 \mathrm{clams} / 0.06 \mathrm{~m}^{2}$ between 1985 and 1993 (Table 3.2). The lowest mean infaunal density was found in 1990 , approximately 6 months after fill placement. In addition, the 1990 survey had the lowest percentage of sampling stations from the fill area with infaunal bivalves present $(21 \%, 7 \%$, and $26 \%$ in 1985, 1930, and 1993, respectively). These two measures indicate that infaunal bivalve populations in the fill area may have been clepressed slightly after fill placement, but were very similar in pre-fill and current surveys.

In reference areas, infaunal bivalve density has been relatively stable. Mean bivalve density in reference areas has ranged from 2.21 to $4.60 \mathrm{clams} / 0.06 \mathrm{~m}^{2}$ between 1985 and 1993 (Table 3.2). The highest density was found in 1993. Juvenile clams $(<1.3 \mathrm{~cm})$ were present at $+2-\mathrm{ft}$ stations in 1993 when small individuals of Macoma sp. were found at Transect 8, and $P$. staminea plus $S$. giganteus were found at Transect 6 . 
Sampling stations in the reference area with a relatively high density of clams ( $\geq 6 \mathrm{clams} / 0.06 \mathrm{~m}^{2}$ ) were more frequent in 1993 than in previous years $(p<0.1)$. Nonetheless, the same analysis indicated that sampling stations with a modest density of $\mathrm{clams}$ ( 1 to $5 \mathrm{clams} / 0.06 \mathrm{~m}^{2}$ ) were less frequent in 1993 than in 1985 or 1990 ( $p<0.1)$. The later finding was based, however, on a small number of observations (i.e., 2) in 1993. The biological significance of these findings is unclear.

The goal of infaunal bivalve habitat enhancement encompasses the entire intertidal area. Therefore, an analysis of bivalve density was conducted that included stations from the entire tidal range sampled at transects where fill was placed (+2 ft to $0 \mathrm{ft}$ MLLW stations at Transects 2 through 9). This analysis also failed to indicate any statistically significant difference in bivalve density between years. Nevertheless, three positive indicators from this area in 1993 are 1) a increase since 1990 in the percentage of stations where clams were found $(25 \%, 10 \%$, and $26 \%$ in 1985,1990 , and 1993 , respectively), 2) a greater number of stations with a relatively high infaunal bivalve density (7, 5, and 9 stations in 1985, 1990, and 1993, respectively), 3) a greater total number of bivalves found (108, 69, and 111 in 1985, 1990, and 1993, respectively).

\subsubsection{Bivalve Biomass and Valve Length}

The mean total biomass of infaunal bivalves was estimated to be lower in 1993 than in previous years over the entire study area (Table 3.1) and in both fill and reference areas (Table 3.2). A significant decrease ( 000.05$)$ has occurred since 1985 in the number of stations with relatively high infaunal bivalve biomass (>40 mg dry weight). This finding, however, may not be an accurate assessment. Discrepancies in the data from different years suggest that uncontrolled factors (e.g., stomach content contribution to tissue weight, seasonal variation in gonadal and other tissues) contribute to variability in dry tissue weight.

Clam valve (shell) length, in combination with clam density, is a more controlled measure of changes in biomass than tissue dry weight. The mean valve length for the three dominant species of infaunal bivalves is summarized for 1985, 1990, and 1993 in Table 3.3. This table incorporates clam data from 


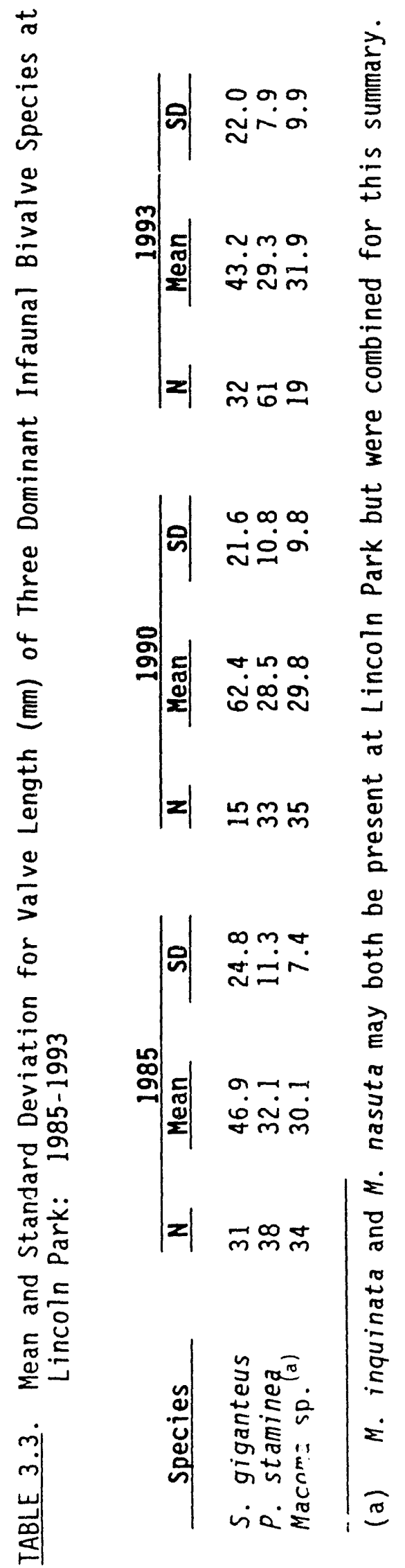


both $f i l l$ and reference area stations because few infaunal bivalves are present in the fill area. The mean and standard deviation in valve length have been consistent between 1985 and 1993. This indicates that the age distribution of the dominant infaunal bivalve species has remained stable after fill placement. These data provide no indication that infaunal bivalve recruitment to the beach has been impaired or enhancec by fill placement and
subsequent redistribution.

\subsubsection{Species Composition}

The population of infaunal bivalves in intertidal areas of Lincoln Park is dominated by three clams, P. staminea, S. giganteus, and Macoma sp., which have constituted approximately $80 \%$ or more of clams sampled each year. The littleneck clam, $P$. staminea, has consistently been the dominant species found. Three additional species comprise a small percentage of clam samples (<6\% of all clams found) in all 3 years: Tresus capax (gaper or horse clam), Clinocardium nuttallii (cockle), and Tapes japonica.

Although all Macoma collected in 1993 were initially identified as M. nasuta, previous studies have identified all Macoma as M. inquinata. Clam shells from bivalve collections in March 1993 were discarded before this discrepancy could be clarified. Macoma found in July between Transects 5 and 6 were identified as M. inquinata. It is likely that some Macoma were misidentified in March 1993. Nevertheless, both species of Macoma may be present at Lincoln Park beach.

\subsection{EELGRASS}

As has been shown in previous studies (Thom and Hampel 1985; Thom and Hamilton 1991), Zostera has a limited distribution at Lincoln Park. In most areas where eelgrass is found, it is confined to a narrow band at lower intertidal and shallow subtidal depths. Eelgrass was most healthy (i.e., dense and long) in areas dominated by sandy substrate. Smaller patches and sparse densities of eelgrass were found where cobble is mixed with sand on the substrate surface. As was found in 1990, not all eelgrass patches identified in 1985 were found in 1993. Yet, healthy beds of eelgrass were found at locations where eelgrass had not formerly been surveyed. Findings from 
eelgrass surveys in 1993 are summarized in Table 3.4. The locations of eelgrass patches are shown in Figure 3.1 .

The most extensive eelgrass beds in the study area are located north of the reference transect (Transect 10). Clean sand forms the substrate for eelgrass beds that start at approximately $-2 \mathrm{ft} M L L W$ and extend several meters into deeper water. The outer limits of these eelgrass beds could not be located because of water depth and wave activity. North of Transect 10, an area $2^{+} \mathrm{m}$ wide and $63 \mathrm{~m}$ long has eelgrass covering $40 \%$ of the surface in numerous patches from one to several meters long. These could not be identified as patches defined in previous studies (i.e., patches 1 - 5). Nevertheless, eelgrass beds in this area appear to have expanded approximately $20 \mathrm{~m}$ farther northward since 1990. To the north, eelgrass ends where the substrate becomes dominated by cobble. In 1993, no eelgrass was found south of Transect 10 (toward the ferry dock) where clean sand would appear to provide a suitable substrate for eelgrass.

In the lower intertidal areas adjacent to the fill area, most of the eelgrass patches surveyed in 1990 remained in 1993. Moreover, eelgrass has become established in new patches not previously identified (Táule 3.4). A new, small (2- $\mathrm{m}^{2}$ area) patch of eelgrass was found south of Transect 6 (patch 6.5). Patch 7, not found in 1989 (Thom and Hallum 1989) or 1990 (Thom and Hamilton 1991), was well established in 1993. In addition, several small, sparse patches of eelgrass were found inshore from patches $10-15$, at approximately -1 ft MLLW in the area north of Transect 3 (patch 20).

In 1993, the densest eeigrass patches adjacent to the original fill area were located in a narrow band ( 1 to $2 \mathrm{~m}$ wide) near Williams Point. Formerly identified as patches $10-15$, the eelgrass formed two distinct patches in 1993. This eelgrass was located in a band of sandy substrate with $-2.5 \mathrm{ft}$ $(0.75 \mathrm{~m})$ MLLW as the upper limit. The eelgrass was surrounded by brown algae, Alaria and Sargassum, that was growing on cobble and boulders at lower and higher elevations on the shore.

The lower intertidal and subtidal beach elevations from the fill area (between Transects 2 and 9 ) has only marginal eelgrass substrate. Two relatively large beds of eelgrass, patches 17 and 18 , are patchy and sparse 


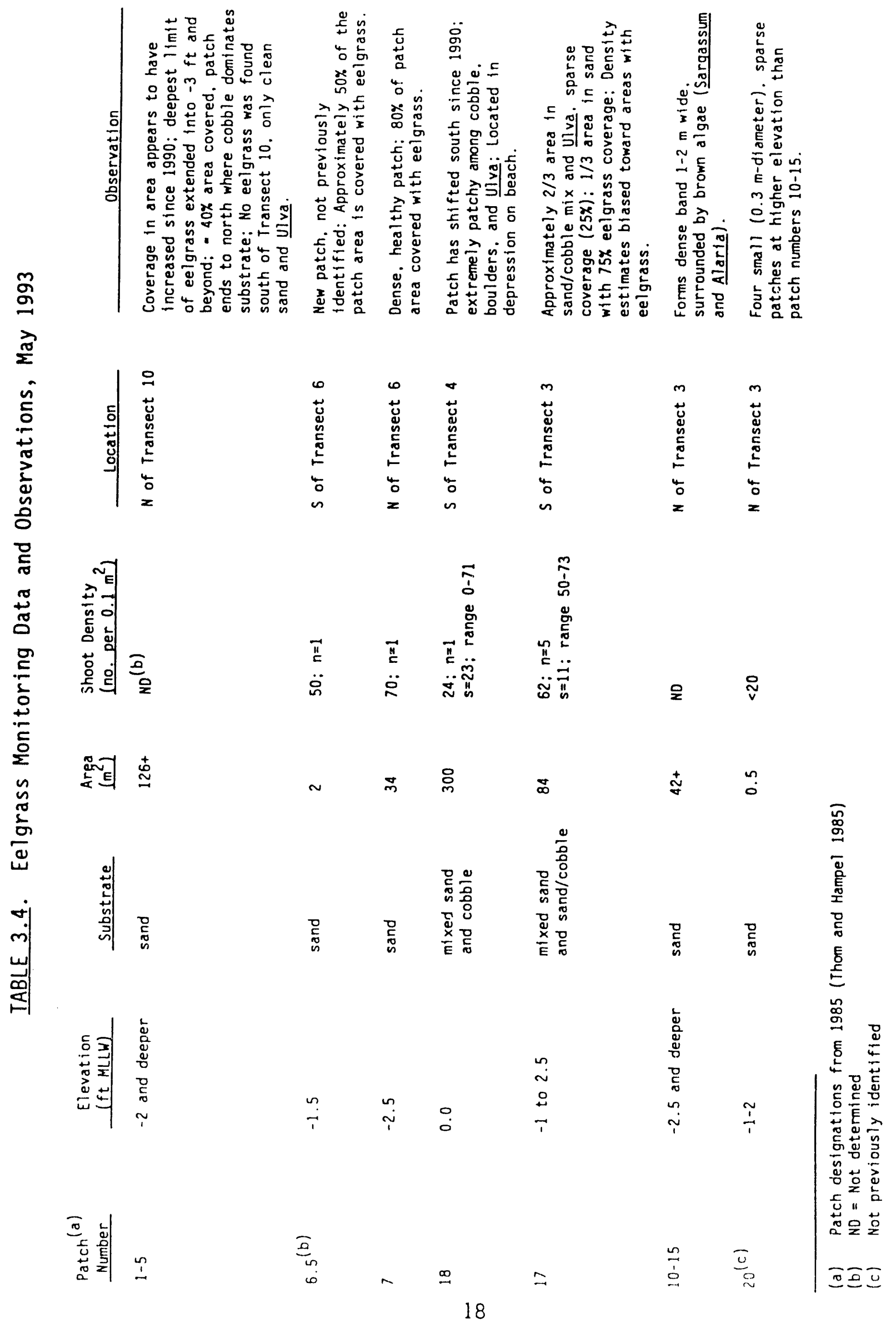


beds located in mixed sand and cobble. Where patch 18 covers an area $400 \%$ larger than that found in $1990\left(300 \mathrm{~m}^{2} \mathrm{vs} .72 \mathrm{~m}^{2}\right)$, patch 17 is only $15 \%$ of its 1990 size $\left(84 \mathrm{~m}^{2}\right.$ vs. $\left.540 \mathrm{~m}^{2}\right)$. Two other patches (6.5 and 7) are small but. dense, healthy beds located in small pockets of sand.

The beach at Lincoln Park in the fill area is subject to pounding waves when strong southerly winds occur. Periods of high wave energy that coincide with low tides could cause significant destruction to eelgrass beds through erosion of sediments and transport of larger substrate materials. It appears that interannual variability of eelgrass beds is a natural phenomenon at Lincoln Park, and it may be related to wave energy and sediment transport. Long-term health of Zostera beds is dependent on the presence of suitable suistrate (e.g., sand with relatively little gravel and cobble). It is unclear if changes to eelgrass beds adjacent to the fill area are related to introduction of coarser materials from the fill or other natural events.

Recreational clam digging is another factor that may contribute to instability of eelgrass in some portions of the beach at Lincoln Park. In July 1993, the beach between Transects 4 and 5 near -2-ft and $0-\mathrm{ft}$ elevations was widely disturbed by recent clamming holes. Digging had occurred in an area of sparse eelgrass colonization (patch 18). Fortunately, most eelgrass is located below $0 \mathrm{ft}$ MLLW in areas where access by recreational clammers is limited by the tidal cycle.

Long-term viability was the primary consideration in selection of the site for eelgrass enhancement through transplanting. Substrate, tidal elevation, and competition from other marine vegetation were evaluated to maximize the potential for successful transplanting. This site should be monitored in the future to determine the success of the transplant effort. 


\subsection{CONCLUSIONS}

The seawall from the study area at Lincoln Park remains protected by fill material placed in 1985. Nevertheless, a migration of fill material appears to have occurred onto lower beach elevations (+2 ft MLLW) and toward the south, toward Transect 10.

The clam populations at Lincoln Park appear to be stable. Three measures of the infaunal bivalve community - density, size, and species distribution indicate that there has been no measurable change in populations at Lincoln park since 1985. Although enhancement of infaunal bivalve populations at Lincoln Park beach has not been realized, several findings imply positive developments in infaunal bivalve populations at Lincoln Park. The percentage of sampling stations with infaunal bivalves, the number of stations with relatively high bivalve density $\left(\geq 6 \mathrm{clams} / 0.06 \mathrm{~m}^{2}\right.$ ), and the total number of clams found at the beach in or beliw the fill area all show improvement since 1990. The influence of recreationa: ciam harvesting on the infaunal bivalve population is an uncontrolled variable that impacts the results of intertidal surveys.

While the size and shape of many of the eelgrass patches have changed since 1985 and 1990, viable beds remain established in most areas where Zostera had previously been surveyed. Moreover, eelgrass was found in 1992 in two locations where it had not formerly been located. The limiting factor at Lincoln Park appears to be suitable substrate. The majority of the lower intertidal and shallow subtidal beach at Lincoln Park is dominated by gravel, cobble, and boulders. Eelgrass is currently established in some areas with mixed sand and cobble substrates, but it is generaliy very sparse and small. 


\subsection{REFERENCES}

Hiss, J., J. Schroeder, and S. Lind. 1988. The Effect of Beach Nourishment on Salmonid Resources of Lincoln Park Beach, Seattle, Washington: Pre-Project Conditions. Report to Seattle District Corps of Engineers. U.S. Fish and Wildlife Service, Olympia, Washington.

Snedecor, G. W., and W. G. Cochran. 1980. Statistical Methods, Seventh Edition. The Iowa State University Press, Ames, Iowa.

Thom, R. M. 1988. Lincoln Park Beach Eelgrass Baseline Study. Final Report to the U.S. Army Corps of Engineers. Evans-Hamilton, Inc., Seattle, Washington.

Thom, R. M., and L. Hallum. 1989. Beach Nourishment, Post-Project Ecologrcal Monitoring at Lincoln Park Beach: Initial Observations, Summer 1989. Final Report to the U.S. Corps of Engineers, Seattle District. Fisheries Research Institute, University of Washington, Seattle, Washington.

Thom, R. M., and L. Hamilton. 1991. Lincoln Park Shoreline Erosion Control Project: Post-Construction Monitoring of Eelgrass, Inf aunal Bivalves, and Macroalgae, 1990. FRI-UW-9104. Fisheries Research Institute, School of Fisheries, University of Washington, Seattle, Washington.

Thom, R. M., and J. J. Hampel. 1985. Lincoln Park Benthic Resource Assessment/Enhancement Study. Final Report to the U.S. Army Corps of Engineers. Evans-Hamilton, Inc., Seattle, Washington. 
APPENDIX

DATA TABLES 
IABLE A.1. Data File for Bivalve Length and Dry Weight Data, Lincoln Park 1993

Lincoln Park Bivalve Survey

March 1993

Filename: bivalve.wk3

\begin{tabular}{|c|c|c|}
\hline Species code & $\begin{array}{l}1=\text { S. giganteus } \\
2=P . \text { staminea } \\
3=T \cdot \text { capax } \\
4=M \cdot \text { nasuta } \\
5=C \text {.nuttal } 1 \mathrm{i}\end{array}$ & $\begin{array}{l}\text { butter } \\
\text { littleneck } \\
\text { gaper/horse } \\
\text { bon`nose } \\
\text { cockle }\end{array}$ \\
\hline
\end{tabular}

\section{Data\# Transect Elevation Species}

Tissue

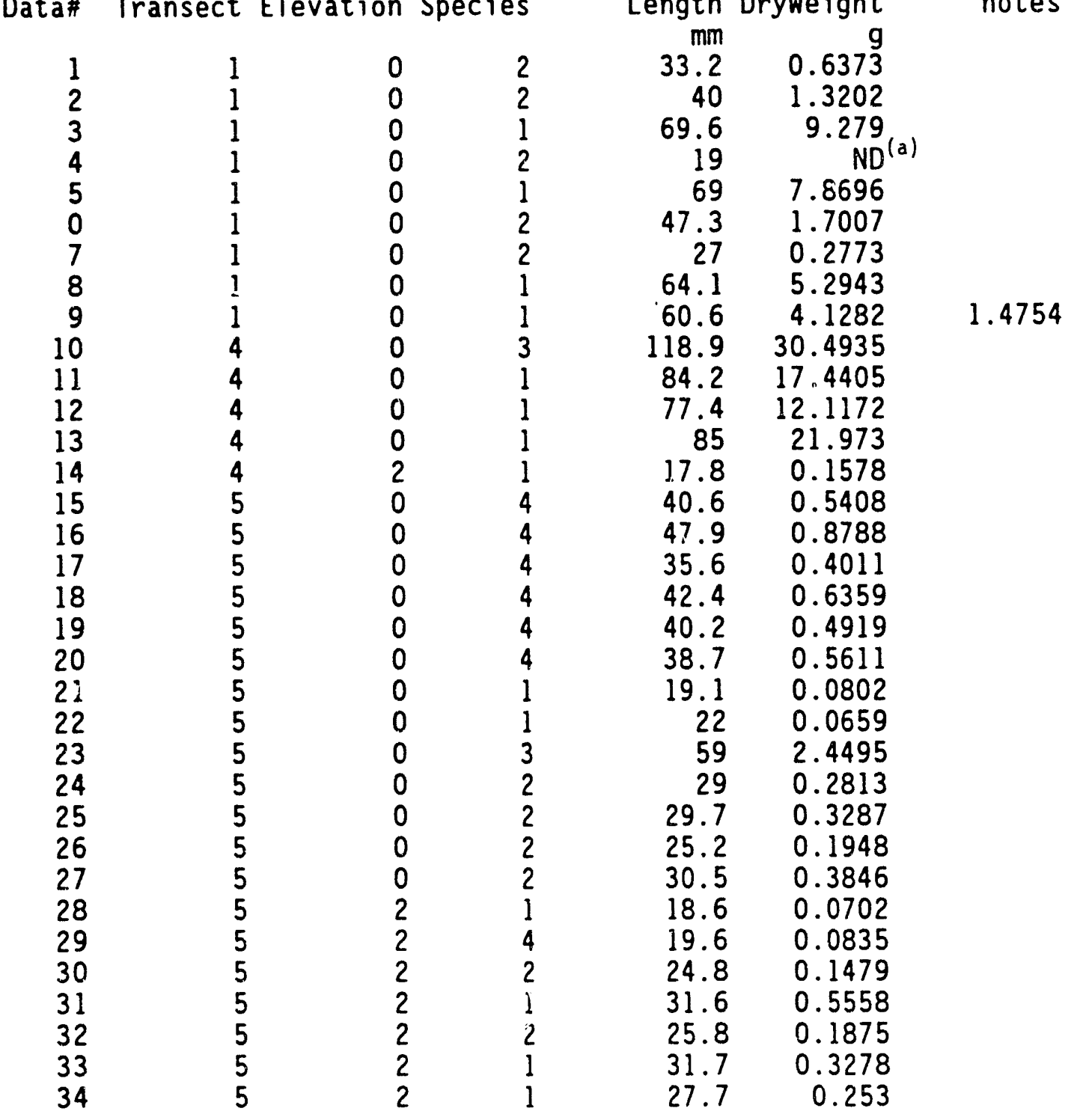

A. 1 
TABLE A.1. CONTD.

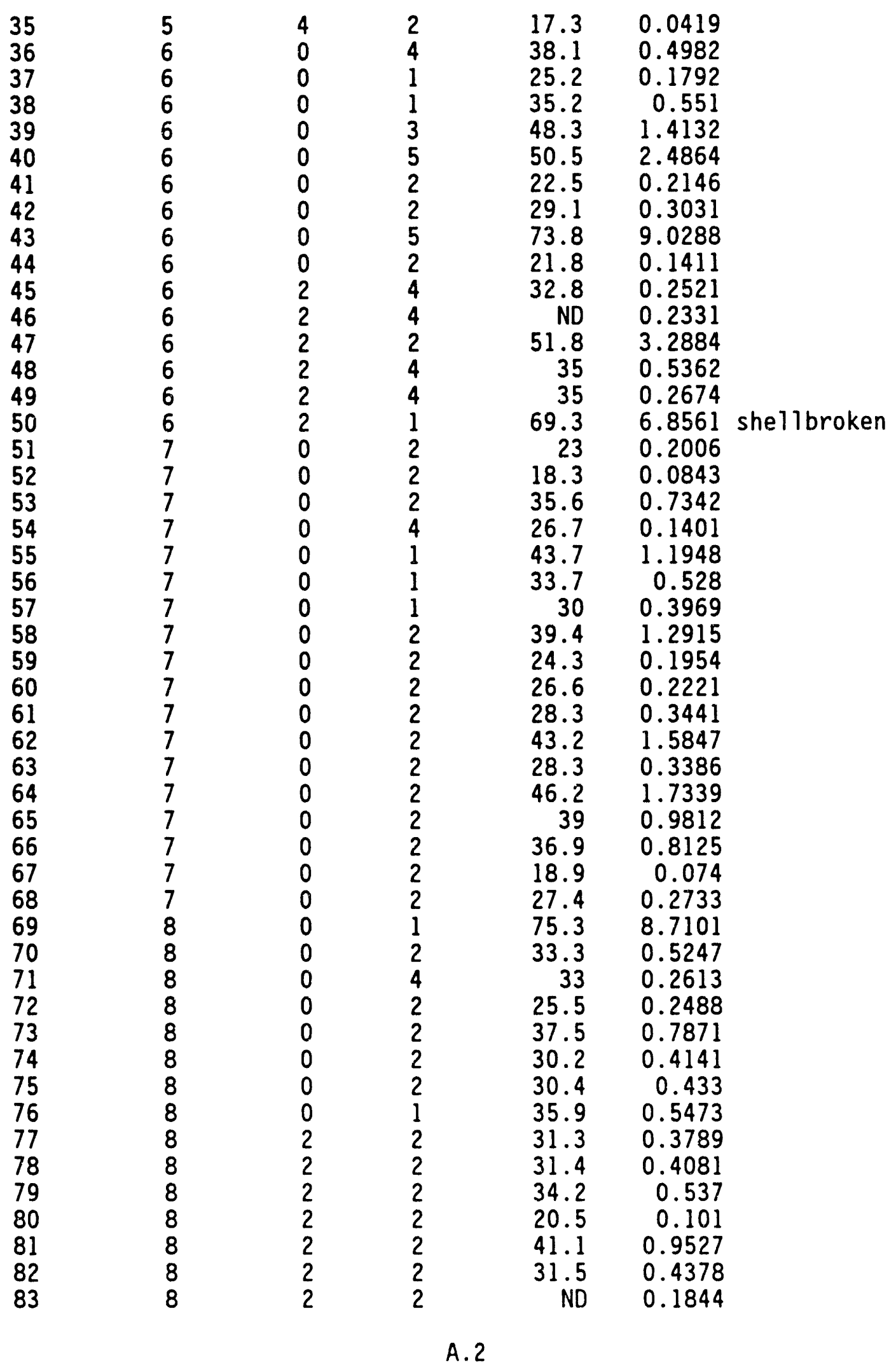


IABLE A.1. CONTD.

\begin{tabular}{|c|c|c|c|c|c|c|}
\hline $\begin{array}{l}84 \\
85 \\
86 \\
87 \\
88 \\
89 \\
90 \\
91 \\
92 \\
93 \\
94 \\
95 \\
96 \\
97 \\
98 \\
99 \\
100 \\
101 \\
102 \\
103 \\
104 \\
105 \\
106 \\
107 \\
108 \\
109 \\
110 \\
111 \\
112 \\
113 \\
114 \\
115 \\
116 \\
117 \\
118 \\
119 \\
120 \\
121 \\
122 \\
123 \\
124 \\
125\end{array}$ & $\begin{array}{r}8 \\
8 \\
8 \\
8 \\
8 \\
8 \\
8 \\
8 \\
8 \\
8 \\
8 \\
8 \\
8 \\
8 \\
8 \\
8 \\
8 \\
8 \\
8 \\
8 \\
8 \\
8 \\
8 \\
8.5 \\
8.5 \\
8.5 \\
8.5 \\
8.5 \\
8.5 \\
8.5 \\
9 \\
9 \\
9 \\
9 \\
9 \\
9 \\
9 \\
9 \\
9 \\
9 \\
9 \\
10\end{array}$ & $\begin{array}{l}2 \\
2 \\
2 \\
2 \\
2 \\
2 \\
2 \\
2 \\
2 \\
2 \\
2 \\
2 \\
2 \\
2 \\
2 \\
2 \\
2 \\
2 \\
2 \\
2 \\
2 \\
2 \\
4 \\
0 \\
0 \\
0 \\
0 \\
0 \\
0 \\
4 \\
2 \\
2 \\
2 \\
2 \\
2 \\
2 \\
2 \\
2 \\
4 \\
6 \\
6 \\
0\end{array}$ & $\begin{array}{l}3 \\
3 \\
4 \\
3 \\
2 \\
2 \\
2 \\
2 \\
1 \\
1 \\
1 \\
1 \\
1 \\
1 \\
2 \\
1 \\
2 \\
2 \\
2 \\
2 \\
2 \\
2 \\
1 \\
2 \\
4 \\
1 \\
2 \\
2 \\
2 \\
2 \\
4 \\
4 \\
4 \\
4 \\
6 \\
2 \\
2 \\
1 \\
2 \\
2 \\
2 \\
3\end{array}$ & $\begin{array}{r}33.4 \\
43.5 \\
18.1 \\
\text { ND } \\
17.5 \\
28.2 \\
18.4 \\
27.5 \\
33.4 \\
22.1 \\
29.5 \\
34.4 \\
18.9 \\
37.5 \\
22.2 \\
32.8 \\
26.7 \\
27 \\
33.1 \\
24.6 \\
27.8 \\
31 \\
21.4 \\
N D \\
38.4 \\
76.2 \\
31.2 \\
27.8 \\
46.3 \\
29.1 \\
34 \\
19 \\
12.2 \\
19.4 \\
36.7 \\
21.8 \\
22 \\
50.4 \\
21 \\
26.6 \\
22.5 \\
40.7\end{array}$ & $\begin{array}{r}0.2708 \\
0.889 \\
0.0552 \\
0.9531 \\
0.1278 \\
0.3042 \\
0.0954 \\
0.2899 \\
0.4295 \\
0.1212 \\
0.2691 \\
0.5415 \\
0.094 \\
0.6167 \\
0.201 \\
0.4125 \\
0.2473 \\
0.2757 \\
0.5224 \\
0.2022 \\
0.2949 \\
0.3686 \\
0.1372 \\
0.9434 \\
0.473 \\
6.9407 \\
0.3964 \\
0.3343 \\
1.5667 \\
0.3043 \\
0.2552 \\
0.056 \\
0.0172 \\
0.0629 \\
0.5021 \\
0.1096 \\
0.1913 \\
2.7041 \\
0.2193 \\
0.2553 \\
0.1669 \\
0.7224\end{array}$ & shellbroken \\
\hline
\end{tabular}

(a) $N D=$ No data collected 
TABLE A.2. Data File for Bivalve Density Data, Lincoln Park 1993

Lincoln Park Bivalve Survey

March 1993

Filename: bivsum.wk3

$$
\begin{aligned}
& \text { Species code } \\
& 1=\text { S.giganteus } \\
& 2 \text { = P.staminea } \\
& 3=T \text {. capax } \\
& 4=\text { M.nasuta } \\
& 5=\text { C.nuttalli } \\
& 6=T \text {.japonica }
\end{aligned}
$$

butter

littleneck

gaper/horse

bentnose

cockle

Japanese littleneck

Total Total Total Total Total Total Total

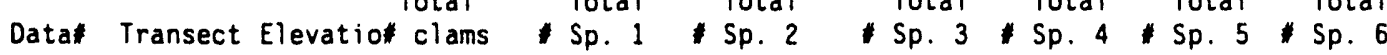

$\begin{array}{rrrr}1 & 1 & 0 & 9 \\ 2 & 1 & 2 & 0 \\ 3 & 1 & 4 & 0 \\ 4 & 1 & 6 & 0 \\ 5 & 2 & 0 & 0 \\ 6 & 2 & 2 & 0 \\ 7 & 2 & 4 & 0 \\ 8 & 2 & 6 & 0 \\ 9 & 3 & 0 & 0 \\ 10 & 3 & 2 & 0 \\ 11 & 3 & 4 & 0 \\ 12 & 3 & 6 & 0 \\ 13 & 4 & 0 & 0 \\ 14 & 4 & 2 & 1 \\ 15 & 4 & 4 & 0 \\ 16 & 4 & 6 & 0 \\ 17 & 5 & 0 & 14 \\ 18 & 5 & 2 & 7 \\ 19 & 5 & 4 & 1 \\ 20 & 5 & 6 & 0 \\ 21 & 6 & 0 & 9 \\ 22 & 6 & 2 & 6 \\ 23 & 6 & 4 & 0 \\ 24 & 6 & 6 & 0 \\ 25 & 7 & 0 & 18 \\ 26 & 7 & 2 & 0 \\ 27 & 7 & 4 & 0 \\ 28 & 7 & 6 & 0 \\ 29 & 8 & 0 & 8 \\ 30 & 8 & 2 & 29 \\ 31 & 8 & 4 & 1 \\ 32 & 8 & 6 & 0 \\ 33 & 8.5 & 0 & 6 \\ 34 & 8.5 & 4 & 1 \\ 35 & 5.5 & 4 & 0 \\ 36 & 6.5 & 4 & 0 \\ 37 & 9 & 0 & 0 \\ 38 & 9 & 2 & 7 \\ 39 & 9 & 4 & 1 \\ 40 & 9 & 6 & 2 \\ 41 & 10 & 0 & 1 \\ 42 & 10 & 2 & 0 \\ 43 & 10 & 4 & 0 \\ 44 & 10 & 6 & 0 \\ & & & \end{array}$

$$
\begin{aligned}
& 4 \\
& 0 \\
& 0 \\
& 0 \\
& 0 \\
& 0 \\
& 0 \\
& 0 \\
& 0 \\
& 0 \\
& 0 \\
& 0 \\
& 0 \\
& 1 \\
& 0 \\
& 0 \\
& 3 \\
& 4 \\
& 0 \\
& 0 \\
& 2 \\
& 1 \\
& 0 \\
& 0 \\
& 3 \\
& 0 \\
& 0 \\
& 0 \\
& 2 \\
& 7 \\
& 1 \\
& 0 \\
& 1 \\
& 0 \\
& 0 \\
& 0 \\
& 0 \\
& 1 \\
& 0 \\
& 0 \\
& 0 \\
& 0 \\
& 0 \\
& 0
\end{aligned}
$$

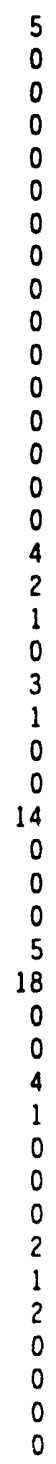

$\begin{array}{llll}0 & 0 & 0 & 0 \\ 0 & 0 & 0 & 0 \\ 0 & 0 & 0 & 0 \\ 0 & 0 & 0 & 0 \\ 0 & 0 & 0 & 0 \\ 0 & 0 & 0 & 0 \\ 0 & 0 & 0 & 0 \\ 0 & 0 & 0 & 0 \\ 0 & 0 & 0 & 0 \\ 0 & 0 & 0 & 0 \\ 0 & 0 & 0 & 0 \\ 0 & 0 & 0 & 0 \\ 0 & 0 & 0 & 0 \\ 0 & 0 & 0 & 0 \\ 0 & 0 & 0 & 0 \\ 0 & 0 & 0 & 0 \\ 1 & 6 & 0 & 0 \\ 0 & 1 & 0 & 0 \\ 0 & 0 & 0 & 0 \\ 0 & 0 & 0 & 0 \\ 1 & 1 & 2 & 0 \\ 0 & 4 & 0 & 0 \\ 0 & 0 & 0 & 0 \\ 0 & 0 & 0 & 0 \\ 0 & 1 & 0 & 0 \\ 0 & 0 & 0 & 0 \\ 0 & 0 & 0 & 0 \\ 0 & 0 & 0 & 0 \\ 0 & 1 & 0 & 0 \\ 3 & 1 & 0 & 0 \\ 0 & 0 & 0 & 0 \\ 0 & 0 & 0 & 0 \\ 0 & 1 & 0 & 0 \\ 0 & 0 & 0 & 0 \\ 0 & 0 & 0 & 0 \\ 0 & 0 & 0 & 0 \\ 0 & 0 & 0 & 0 \\ 0 & 4 & 0 & 1 \\ 0 & 0 & 0 & 0 \\ 0 & 0 & 0 & 0 \\ 1 & 0 & 0 & 0 \\ 0 & 0 & 0 & 0 \\ 0 & 0 & 0 & 0 \\ 0 & 0 & 0 & 0\end{array}$

\section{A. 4}


IABLE A.3. Data File for Substrate Characterization Data, Lincoln Park 1993

Lincoln Park Study

March 1993

Filename: cover.wk3

$$
\text { substrate codes } \quad \begin{aligned}
& 1=\text { cobble } \\
& 2=\text { gravel } \\
& 3=\text { sand }
\end{aligned}
$$

$\begin{array}{rrrrr}\text { Transect } & \text { Elevation } & \text { Substrate } & \text { Original } & \text { Data } \\ \text { T } & \text { Cover } \\ 1 & 0 & 1 & 11 & 22 \\ 1 & 0 & 2 & 39 & 78 \\ 1 & 0 & 3 & 0 & 0 \\ 1 & 2 & 1 & 48 & 96 \\ 1 & 2 & 2 & 2 & 4 \\ 1 & 2 & 3 & 0 & 0 \\ 1 & 4 & 1 & 46 & 92 \\ 1 & 4 & 2 & 2 & 4 \\ 1 & 4 & 3 & 2 & 4 \\ 1 & 6 & 1 & 44 & 88 \\ 1 & 6 & 2 & 5 & 10 \\ 1 & 6 & 3 & 1 & 2 \\ 2 & 0 & 1 & 7 & 14 \\ 2 & 0 & 2 & 35 & 70 \\ 2 & 0 & 3 & 8 & 16 \\ 2 & 2 & 1 & 12 & 24 \\ 2 & 2 & 2 & 29 & 58 \\ 2 & 2 & 3 & 9 & 18 \\ 2 & 4 & 1 & 1 & 2 \\ 2 & 4 & 2 & 4 & 8 \\ 2 & 4 & 3 & 45 & 90 \\ 2 & 6 & 1 & 10 & 20 \\ 2 & 6 & 2 & 36 & 72 \\ 2 & 6 & 3 & 4 & 8 \\ 3 & 0 & 1 & 24 & 48 \\ 3 & 0 & 2 & 22 & 44 \\ 3 & 0 & 3 & 4 & 8 \\ 3 & 2 & 1 & 5 & 10 \\ 3 & 2 & 2 & 33 & 66 \\ 3 & 2 & 3 & 12 & 24 \\ 3 & 4 & 1 & 1 & 2 \\ 3 & 4 & 2 & 13 & 26 \\ 3 & 4 & 3 & 36 & 72 \\ 3 & 6 & 1 & 0 & 0 \\ 3 & 6 & 2 & 44 & 88 \\ 3 & 6 & 3 & 6 & 12 \\ 4 & 0 & 1 & 40 & 80 \\ 4 & 0 & 2 & 0 & 0\end{array}$

A. 5 
TABLE A.3. CONTD.

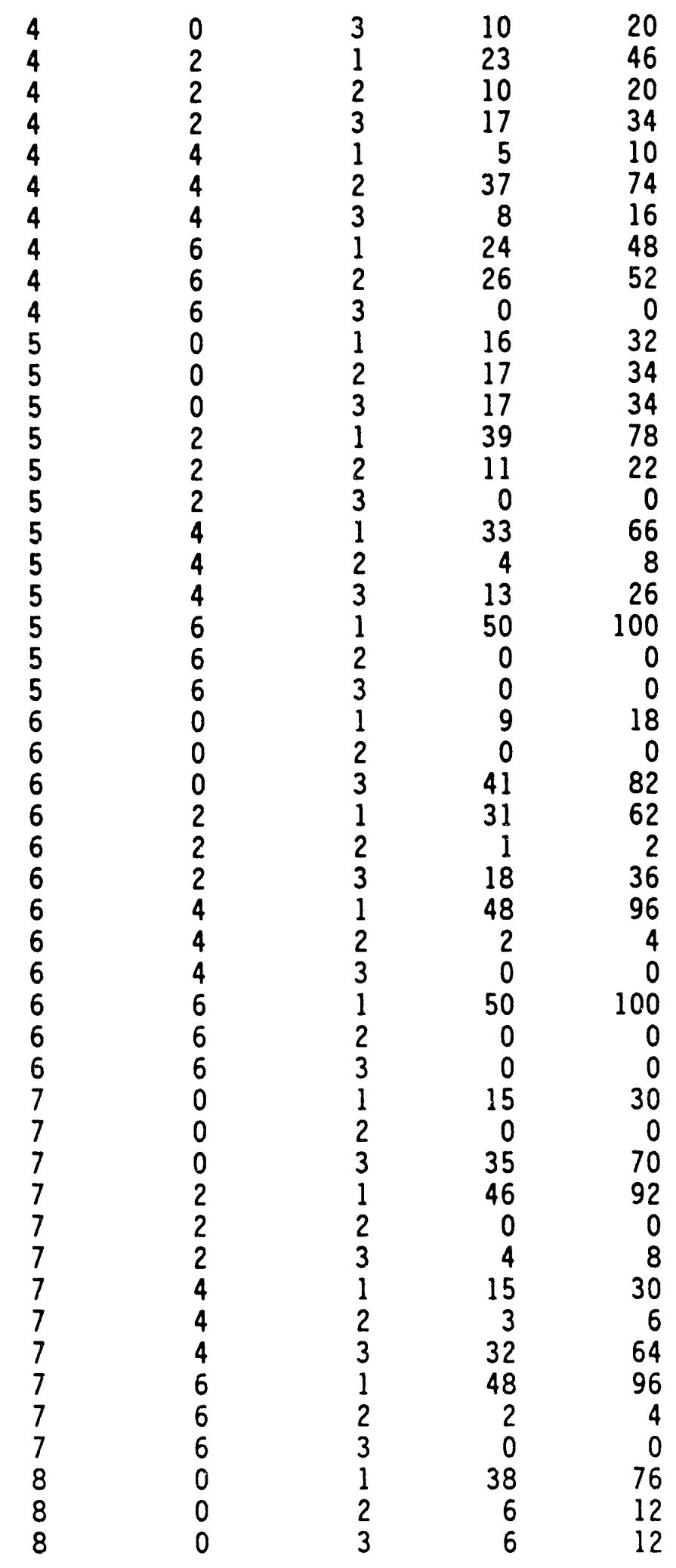

$$
\text { A. } 6
$$


TABLE A.3. CONTD.

$\begin{array}{rrrrr}8 & 2 & 1 & 44 & 88 \\ 8 & 2 & 2 & 5 & 10 \\ 8 & 2 & 3 & 1 & 2 \\ 8 & 4 & 1 & 44 & 88 \\ 8 & 4 & 2 & 4 & 8 \\ 8 & 4 & 3 & 2 & 4 \\ 8 & 6 & 1 & 41 & 82 \\ 8 & 6 & 2 & 9 & 18 \\ 8 & 6 & 3 & 0 & 0 \\ 8.5 & 0 & 1 & 45 & 90 \\ 8.5 & 0 & 2 & 3 & 6 \\ 8.5 & 0 & 3 & 2 & 4 \\ 8.5 & 2 & 1 & N D & 0 \\ 8.5 & 2 & 2 & N D & 0 \\ 8.5 & 2 & 3 & N D & 0 \\ 8.5 & 4 & 1 & 49 & 98 \\ 8.5 & 4 & 2 & 0 & 0 \\ 8.5 & 4 & 3 & 1 & 2 \\ 8.5 & 6 & 1 & N D & 0 \\ 8.5 & 6 & 2 & N D & 0 \\ 8.5 & 6 & 3 & N D & 0 \\ 9 & 0 & 1 & 34 & 68 \\ 9 & 0 & 2 & 6 & 12 \\ 9 & 0 & 3 & 10 & 20 \\ 9 & 2 & 1 & 17 & 34 \\ 9 & 2 & 2 & 33 & 66 \\ 9 & 2 & 3 & 0 & 0 \\ 9 & 4 & 1 & 18 & 36 \\ 9 & 4 & 2 & 30 & 60 \\ 9 & 4 & 3 & 2 & 4 \\ 9 & 6 & 1 & 25 & 50 \\ 9 & 6 & 2 & 25 & 50 \\ 9 & 6 & 3 & 0 & 0 \\ 10 & 0 & 1 & 3 & 6 \\ 10 & 0 & 2 & 3 & 6 \\ 10 & 0 & 3 & 44 & 88 \\ 10 & 2 & 1 & 21 & 42 \\ 10 & 2 & 2 & 25 & 50 \\ 10 & 2 & 3 & 4 & 8 \\ 10 & 4 & 1 & 9 & 18 \\ 10 & 4 & 2 & 37 & 74 \\ 10 & 4 & 3 & 4 & 8 \\ 10 & 6 & 1 & 9 & 18 \\ 10 & 6 & 2 & 37 & 74 \\ 10 & 6 & 3 & 4 & 8\end{array}$

(a) $N D=$ No data collected 


\section{DISTRIBUTION}

No. of

Copies

OFFSITE

2 DOE/Office of Scientific and Technical Information

10 Steve Martin

U.S. Army Corps of Engineers 4735 E. Marginal Way South Seattle, WA 98134

\section{ONSITE}

15 Pacific Northwest Laboratory

L. D. Antrim (5)

R. M. Thom

W. W. Gardiner

R. M. Ecker

Publishing Coordination

Technical Report Files (5)
No. of

Copies

Routing

M. J. Graham

P. M. Irving

C. S. Sloane

P. C. Hays (last)

Distr.1 
I
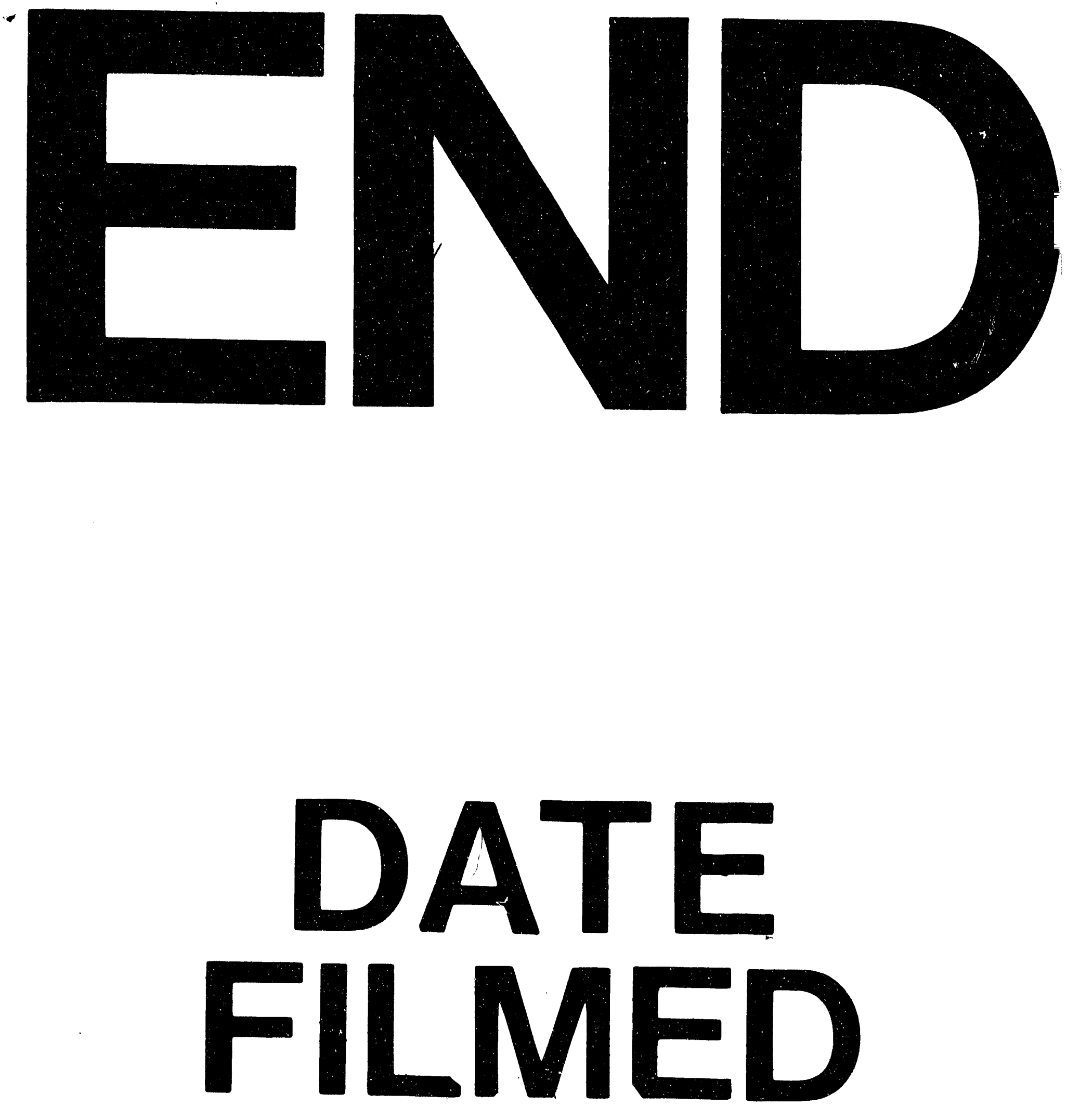

$1 1 / 2 2 \longdiv { 9 3 }$ 
